\title{
DNA ANALYSIS USING LONG-TERM PRESERVED FIXED CYTOGENETIC PREPARATIONS
}

\author{
Hikari NishigakI, ${ }^{1}$ Tsukasa OKuda, ${ }^{1}$ Shigeo Horike, ${ }^{1}$ \\ Shoichiro Tsuda, ${ }^{1}$ Masafumi Taniwaki, ${ }^{1}$ Shinichi Mrsawa, ${ }^{1}$ \\ Johji INAZAWA, ${ }^{2}$ and Tatsuo $\mathrm{ABE}^{2}$ \\ ${ }^{1}$ Third Department of Internal Medicine and ${ }^{2}$ Department of Hygiene, \\ Kyoto Prefectural University of Medicine, Kawaramachi-Hirokoji, \\ Kamigyo-ku, Kyoto 602, Japan
}

\begin{abstract}
Summary DNA was isolated from cell pellets that had been stored in methanol-acetic acid $(3: 1)$ at $-20^{\circ} \mathrm{C}$ up to 6 years. These cell pellets contained high molecular weight DNA sufficient for Southern blot hybridization. The method enables us to study the DNA of a patient after completing chromosome analysis or in cases where DNA samples are otherwise not available.
\end{abstract}

Key Words high molecular weight DNA, DNA extraction, chromosome preparation, Southern blotting, breakpoint cluster region

\section{INTRODUCTION}

DNA analysis is now an important tool to study hematologic diseases (Arnold et al., 1983; Groffen et al., 1984; Kurzrock et al., 1986). However, DNA extraction from fresh blood cells or tissue samples was not performed routinely until recently. Barker et al. (1986) first described a method for extracting DNA from fixed cytogenetic cell pellets stored up to 1.5 years. We extracted DNA from long-preserved fixed cytogenetic material, on which chromosome analysis had been carried out previously; the remainder of the cell pellets had been kept in the methanol acetic acid mixture $(3: 1)$ at $-20^{\circ} \mathrm{C}$ up to 6 years. The purity and the degree of degradation of the DNA were examined. DNA obtained from patients with chronic myelogenous leukemia (CML) was digested, electrophoresed, and hybridized to detect rearrangement within the breakpoint cluster region (bcr).

\section{MATERIALS AND METHODS}

Patients, culture method, procedure for chromosome preparation, and storage of Received September 5, 1988; revised version received October 24, 1988; Accepted October 29, 1988 
cell pellet. The material consisted of blood or bone marrow cells obtained from 19 patients with hematologic malignancies karyotyped in our laboratory; 14 patients with $\mathrm{Ph}^{1}$-positive $\mathrm{CML}$, four with $\mathrm{Ph}^{1}$-negative $\mathrm{CML}$, and one with $\mathrm{Ph}^{1}$-positive acute leukemia. The cells were cultured at $37^{\circ} \mathrm{C}$ in RPMI 1640 medium (GIBCO) supplemented with $15 \%$ fetal bovine serum for $24 \mathrm{hr}$ without mitogen and colcemid was added $1 \mathrm{hr}$ before harvesting. After hypotonic treatment $(0.075 \mathrm{M} \mathrm{KCl}$ for 20 min at $\left.37^{\circ} \mathrm{C}\right)$ the cells were fixed with a $3: 1(\mathrm{v} / \mathrm{v})$ mixture of methanol and glacial acetic acid. After the chromosome preparations were made, the rest of the cells were stored at $-20^{\circ} \mathrm{C}$ in the same fixative. The storage term was 70 months for one sample, 60 months for two, 40 to 59 months for four, 30 to 39 months for two, 20 to 29 months for two, 10 to 19 months for four, and less than 10 months for four.

DNA extraction. After the fixative was removed, each cell pellet was washed several times with absolute ethanol and resuspended in TNE $(20 \mathrm{~mm}$ Tris- $\mathrm{HCl}$ at $\mathrm{pH} 7.4,10 \mathrm{~mm} \mathrm{NaCl}, 0.1 \mathrm{~mm}$ EDTA). DNA was isolated with proteinase $\mathrm{K}$ and phenol/chloroform treatment by the procedure described by Maniatis et al. (1982) and Barker et al. (1986). The absorbance ratio was estimated for the purity of the DNA samples. DNA extracted from 20 fresh blood samples was used as a control.

Southern blotting. Genomic DNA was digested with restriction enzymes ( $B g l \mathrm{II}$, BamHI, HindIII, or EcoRI), electrophoresed in $0.8 \%$ agarose gels, and transferred to nylon membranes (Biodyne, Pall, Glen Cove, N.Y.) by the method of Southern (1975). A 3'-bcr genomic probe (Pr-1, Oncogene Science, Inc., Mineola, N.Y.) and a $5^{\prime}$-bcr cDNA probe (Pr-2, Oncogene Science) were used. The probes were labeled by the multiprime labeling method (Amersham RPN1601) to a specific activity of approximately $1 \times 10^{9} \mathrm{cpm} / \mu \mathrm{g}$ and hybridized. The filters were autoradiographed on Kodak XK-1 films with intensifying screens at $-80^{\circ} \mathrm{C}$ for $16-72 \mathrm{hr}$.

\section{RESULTS}

The DNA was successfully isolated from all the fixed cell pellets. The average yield of DNA extracted was $90.7 \mu \mathrm{g}$ per $0.1 \mathrm{ml}$ of pellet volume. The mean absorbance ratios at $260 / 280 \mathrm{~nm}$ and $260 / 230 \mathrm{~nm}$ were 1.85 and 2.36 , respectively, which did not differ from those of DNA obtained from fresh blood samples (Table 1). Moreover, the ratios for the DNA extracted from material that had been kept more than 3 years did not differ from those from material stored for less than 3 years.

The undigested DNA samples were electrophoresed in $0.7 \%$ agarose gel and stained with ethidium bromide. The DNA extracted from the fixed pellets was partially degraded to various degrees but contained high molecular weight DNA (larger than $23 \mathrm{~kb}$ ); the degree of degradation appeared to be correlated with the term of storage (Fig. 1). Figure 2 shows the results of Southern blotting. All the DNA samples could be digested with restriction enzymes, successfully hybridized to the $b c r$ probes, and revealed clear autoradiographic bands similar to control DNA. However, when compared to the control DNA, it appeared that the DNA 
Table 1. Absorbance ratio and yield of DNA isolated from stored cell pellets.

\begin{tabular}{ccccc}
\hline Specimen & $\begin{array}{c}260 / 280 \mathrm{~nm} \\
(\mathrm{mean} \pm \mathrm{SD})\end{array}$ & $\begin{array}{c}260 / 230 \mathrm{~nm} \\
(\text { mean } \pm \mathrm{SD})\end{array}$ & $\begin{array}{c}\mu \mathrm{gDNA} / 0.1 \mathrm{ml} \\
\text { cell pellet }\end{array}$ & $\begin{array}{c}\text { Number of } \\
\text { samples }\end{array}$ \\
\hline $\begin{array}{c}\text { Fixed pellets } \\
\text { a }\end{array}$ & $1.81 \pm 0.09$ & $2.32 \pm 0.65$ & $107.4 \pm 55.6$ & 8 \\
$\geq 3 \mathrm{yrs}$ & $1.89 \pm 0.22$ & $2.39 \pm 0.63$ & $78.5 \pm 44.2$ & 11 \\
$<3 \mathrm{yrs}$ & $1.80 \pm 0.08$ & $2.31 \pm 0.18$ & - & 20 \\
\hline
\end{tabular}

${ }^{\text {a }}$ Cells stored more than 3 years, or less than 3 years.

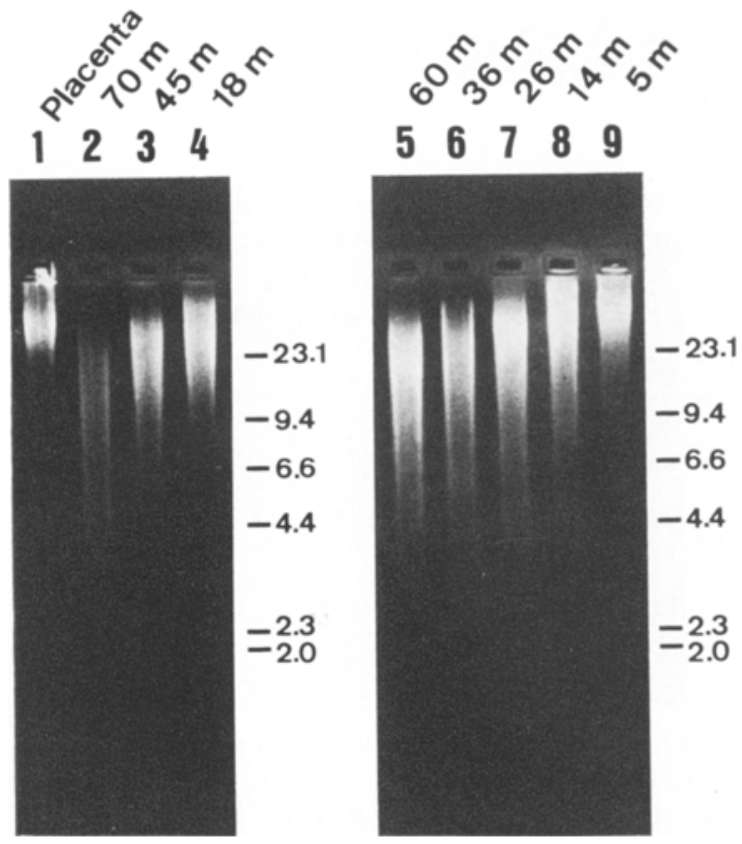

Fig. 1. Agarose gel $(0.7 \%$ ) electrophoresis of undigested DNA isolated from stored cell pellets. Lane 1, placental DNA (control); lanes 2-9, DNA extracted from stored cell pellets. Length of storage is indicated in months at the top. Molecular weight markers, given in kilobase pairs, were lambda phage DNA digested with HindIII.

samples from the fixed cell pellets were somewhat difficult to digest completely with restriction enzymes. We examined a $b c r$ rearrangement in DNA samples extracted from fixed cell pellets in three CML patients with variant $\mathrm{Ph}^{1}$, one $\mathrm{CML}$ with two $\mathrm{Ph}^{1}$ chromosomes, and four $\mathrm{Ph}^{1}$-negative CML. As is shown in Fig. 2 (A, lane 2), the DNA stored for 60 months has a rearranged $b c r$ gene. Two cases of variant $\mathrm{Ph}^{1}$ (stored for 70 months and 50 months, respectively) reveal no rearrangement when digested with EcoRI (Fig. 2B, lanes 2,3). In a patient with CML, we examined 

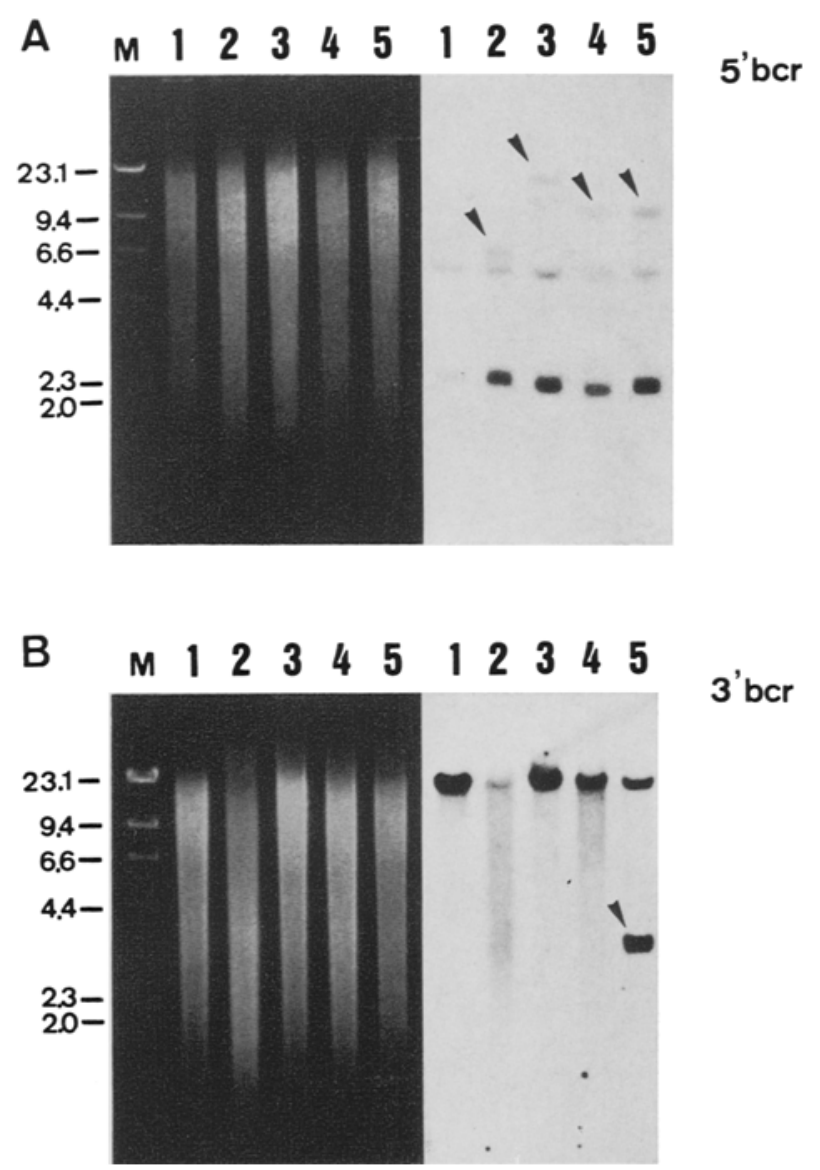

Fig. 2. A: Electrophoresis of DNA samples digested with $B g l l 1$ in $0.8 \%$ agarose gel and stained with ethidium bromide (left). Southern transfer, hybridized to $5 \mathrm{bcr}$ probe (right). B: DNA digested with EcoRI (left), and hybridized to 3'ber (right).

A: Lane 1, placental DNA (control); lane 2, CML with $t(9 ; 22 ; 12)$ (60-month-old pellet); lane 3, CML with standard $\mathrm{Ph}^{1}$ (9-month-old); lane 4, chronic phase CML with standard $\mathrm{Ph}^{1}$ (fresh marrow); lane 5 , accelerated phase of the same patient as lane 4 showing double $\mathrm{Ph}^{1}$ (10-month-old).

B: Lane 1, placental DNA; lane 2, CML with $t(4 ; 18 ; 13 ; 9 ; 22)(70$-month-old pellet); lane 3 , CML with $\mathrm{t}(9 ; 22 ; 15)$ (50-month-old); lane 4 , the same case as A-2 (60-month-old); lane 5, CML with a complex $\mathrm{Ph}^{1}$ involving $\# 9, \# 22$, and $\# 10$ (fresh marrow). M, lambda phage DNA digested with HindIIT. Dashes indicate germ-line bands and arrows indicate rearranged bands.

the ber rearrangement using the $5^{\prime}$-bcr probe (Pr-2) in two DNA samples, one obtained in the chronic phase from fresh blood cells having a standard $\mathrm{Ph}^{1}$ and the other in the accelerated phase from 10-month-old fixed cell pellet having double 
$\mathrm{Ph}^{1}$ in all the metaphases examined. As is shown in Fig. 2 (A, lanes 4, 5), the same bcr rearrangement is detected.

\section{DISCUSSION}

Our results demonstrate that the DNA extracted from a cell pellet kept for up to 6 years at $-20^{\circ} \mathrm{C}$ in a methanol acetate mixture preserves high molecular weight DNA although the chromosome preparation procedure was done at room temperature. The method for extracting DNA from a cell pellet is essentially the same as that used for fresh cells or tissues. Although the isolated DNA contains partially degraded DNA, a sufficient amount of high molecular weight DNA is still contained for Southern blot analysis. The extent of degradation appears to be correlated with the length of storage.

A clonal rearrangement of the bcr gene can be detected using the DNA isolated from mitotic cell pellets of patients with $\mathrm{Ph}^{1}$-positive $\mathrm{CML}$. Thus, the detection of gene rearrangement is possible for specific samples after completing chromosome analysis or in situ hybridization studies as occasion demands.

Acknowledgment The authors thank Dr. James R. Miller for critical reading of the manuscript. This work was supported in part by Grants-in-Aid from the Ministry of Education, Science and Culture of Japan.

\section{REFERENCES}

Arnold, A., Cossman, J., Bakhshi, A., Jaffe, E.S., Waldmann, T.A., and Korsmeyer, S.J. 1983. Immunoglobulin-gene rearrangements as unique clonal markers in human lymphoid neoplasms. N. Engl. J. Med. 309: 1593-1599.

Barker, P.E., Testa, J.R., Parsa, N.Z., and Snyder, R. 1986. High molecular weight DNA from fixed cytogenetic preparations. Am. J. Hum. Genet. 39: 661-668.

Groffen, J., Stephenson, J.R., Heisterkamp, N., de Klein, A., Bartram, C.R., and Grosveld, G. 1984. Philadelphia chromosomal breakpoints are clustered within a limited region, bcr, on chromosome 22. Cell 36: 93-99.

Kurzrock, R., Blick, M.B., Talpaz, M., Velasquez, W.S., Trujillo, J.M., Kouttab, N.M., Kloetzer, W.S., Arlinghaus, R.B., and Gutterman, J.U. 1986. Rearrangement in the breakpoint cluster region and the clinical course in Philadelphia-negative chronic myelogenous leukemia. Ann. Int. Med. 105: 673-679.

Maniatis, T., Fritsch, E.F., and Sambrook, J. 1982. Molecular Cloning, A Laboratory Manual. Cold Spring Harbor Laboratory, Cold Spring Harbor, New York.

Southern, E.M. 1975. Detection of specific sequences among DNA fragments separated by gel electrophoresis. J. Mol. Biol. 98 : 503-517. 